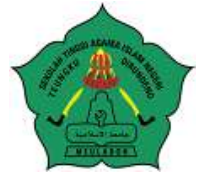

AT-TASYRI' Jurnal Ilmiah Prodi Muamalah

P-ISSN: 2085-2541, E-ISSN: 2715-7865

Volume 12, Nomor 1, Juni 2020

https://ejournal.staindirundeng.ac.id/index.php/Tasyri

\title{
TINJAUAN YURIDIS PENEGAKAN HUKUM MALPRAKTIK DOKTER \\ PADA PELAYANAN KESEHATAN DALAM PERSPEKTIF HUKUM PIDANA
}

\author{
Budi Handoyo S.H., M.H. \\ Dosen Prodi Hukum Tata Negara STAIN Teungku Dirundeng Meulaboh \\ handoyobudi67@gmail.com
}

\begin{abstract}
Abstrak
Masalah malpraktek yang dilakukan oleh dokter dan tenaga medis dalam perawatan kesehatan adalah tindakan yang sangat merugikan pasien dalam melakukan perawatan dapat berakibat pada kondisi medis yang semakin buruk, atau kematian seorang pasien. Kesalahan dalam menjalankan profesi medis akan membentuk pertanggungjawaban pidana. Oleh karena itu, perlu memiliki kepastian hukum khusus di sektor kesehatan untuk memberikan keadilan hukum bagi pasien yang terluka. penelitian yang digunakan adalah penelitian yuridis normatif atau hukum normatif. Pendekatan yang diambil adalah, pendekatan hukum, pendekatan kasus dan pendekatan konseptual. Berdasarkan hasil diskusi, ditemukan bahwa proses penegakan hukum pidana untuk kasus malpraktek medis diatur dalam Pasal 360 ayat (1) dan (2) KUHP yang memuat unsur kelalaian (kulpa) dokter atau tenaga medis. Untuk memberikan jaminan kepastian hukum yang lebih kuat, penegakan hukum untuk malpraktek medis dan petugas kesehatan diatur dalam UU No. 36 tahun 2009 tentang Kesehatan dan UU No. 36 tahun 2014 tentang Tenaga Kesehatan.
\end{abstract}

Kata kunci: Penegakan Hukum Malpraktik dalam Perspektif Hukum Pidana.

\begin{abstract}
The problem of malpractice committed by doctors and medical personnel in health care is an act that is very detrimental to the patient in conducting treatment can result in worsening medical conditions, or death of a patient. Errors in carrying out the medical profession will form criminal liability. Therefore, it is necessary to have a special legal certainty in the health sector to provide legal justice for injured patients. the research used is normative juridical research or normative law. The approach taken is, the law approach, case approach and conceptual approach. Based on the results of the discussion, it was found that the process of criminal law enforcement for medical malpractice cases is regulated in Article 360 paragraph (1) and (2) of the Criminal Code which contains elements of negligence (kulpa) of doctors or medical personnel. To provide a stronger guarantee of legal certainty, law enforcement for medical malpractice and health workers is regulated in Law No. 36 of 2009 concerning Health and Law No. 36 of 2014 concerning Health Workers.
\end{abstract}

Keywords: Malpractic Law Enforcement In Criminal Law Perspective

AT-TASYRI', Vol. 12, No. 1, Juni 2020 


\section{A. PENDAhULUAN}

Kejahatan merupakan suatu fenomena yang komplek yang dapat dipahami dari berbagai sisi yang berbeda. Itu sebabnya dalam keseharian kita dapat menangkap berbagai komentar tentang suatu peristiwa kejahatan yang berbeda satu dengan yang lain. Dalam pengalaman kita ternyata tidak mudah untuk memahami kejahatan itu sendiri. ${ }^{1}$

Kejahatan telah menjadi fenomena yang universal, tidak ada masyarakat tanpa adanya kejahatan. Pada mulanya kejahatan disebabkan faktor kemiskinan. Akan tetapi beberapa waktu kemudian, kejahatan disebabkan oleh kemakmuran. ${ }^{2}$ yaitu Perkembangan Ilmu pengetahuan dan teknologi.

Sejalan dengan pesatnya perkembangan dan kemajuan yang dicapai dibidang ilmu pengetahuan dan teknologi. Maka dunia kedoktoren, khususnya pelayanan kesehatan selalu mengalami tuntutan dan tantangan kemajuan yang tidak kecil artinya. Namun demikian, dalam perkembangan di masa sekarang ini penilaian masyarakat terhadap pelayanan tenaga kesehatan di Indonesia sangat buruk. Akibat negatif dari kemajuan ilmu pengetahuan dan teknologi adalah timbulnya kejahatan dalam di bidang kesehatan atau kriminalitas medis yang mana viktimisasi adalah para pasien. Sahetapy menjelaskan "viktimisasi medis dalam hal ini dapat disebut penyalahgunaan obat bius, alkoholisme, malpraktik di bidang kedokteran, eksperimen kedokteran yang melanggar kode etik."3 Dalam menjalankan profesinya, dokter harus berpedoman pada standar dan etika profesi. Etika kedokteran tersebut merupakan salah satu aplikasi dari filosofi etika. Etika kedokteran dan kode etik profesi medis didasarkan atas prinsip-prinsip beneficence/non-maleficence (memberi manfaat/dan tidak memperburuk keadaan), respect for the autonomy (menghormati hakhak pasien), justice (keadilan) and personal integrity (integritas pribadi tenaga medis). Perilaku yang bertentangan dengan prinsipprinsip tersebutlah yang merupakan suatu malpraktik kedokteran. ${ }^{4}$

Masalah malpraktik dalam pelayanan kesehatan akhir-akhir ini mulai ramai dibicarakan masyarakat diberbagai golongan. Hal ini ditujukkan Karena banyaknya berbagai pengaduan kasus-kasus malpraktik yang diajukan masyarakat terhadap profesi dokter yang telah dianggap merugikan pasien dalam melakukan perawatan. Sebenarnya dengan meningkatnya jumlah pengaduan ini membuktikan bahwa masyarakat telah sadar akan haknya dalam usaha untuk melindungi dirnya sendiri dari tindakan lain yang merugikannya. ${ }^{5}$ Berita tenaga medis dituntut di pengadilan disebabkan adanya unsur kesalahan pengobatan dan pemberian dosis obat tidak sesuai dengan kondisi pasien hingga menyebabkan meninggal, cacat, menambah parah penyakit yang diderita sampai tindakan kurang senonoh yang dilakukan tenaga medis pada pasiennya ${ }^{6}$

Kesalahan dalam menjalankan profesi kedokteran akan membentuk pertanggungjawaban hukum pidana (bergantung sifat

\footnotetext{
${ }^{1}$ Topo Santoso dan Eva Achjani Zulfa, Kriminologi [Jakarta: Rajawali Persi, 2006], hal. 1.

${ }^{2}$ M. Ali. Zaidan, Kebijakan Kriminal [Jakarta: Sinar Grafika, 2016], hal. 1.

${ }^{3}$ C. Maya Indah S. Perlindungan Korban Suatu Perspektif Viktimologi dan Kriminologi [Jakarta: Kencana Prenadamedia Group, 2014], hal. 23.

${ }^{4}$ Hardisman, Opini Masyarakat Tentang Malpraktek Kedokteran, [Majalah Kedokteran Andalas No.1. Vol.36. Januari-Juli 2012], hal. 75.

${ }_{5}^{5}$ Bambang Heryanto, Malpraktik Dokter Dalam Perspektif Hukum \{Jurnal Dinamika Hukum. Vol. 10 No. 2 Mei 2010] hal. 184.

${ }^{6}$ Teguh Sulistia dan Aria Zurnetti, Hukum Pidana Horizon Baru Pasca Reformasi, [ Jakarta: Raja Grafindo Persada, 2012] hal. 222.
} 
akibat kerugian yang timbul) mengandung 3 (tiga) aspek pokok sebagai suatu kesatuan yang tak terpisahkan, ialah pertama perlakuan yang tidak sesuai norma, kedua dilakukan dengan kelalaian, dan ketiga mengandung akibat kerugian dalam hukum. Kerugian dalam hukum adalah kerugian yang dinyatakan hukum dan boleh dipulihkan dengan membebankan tanggungjawab hukum pada pelaku beserta yang terlibat dengan cara hukum. Perlakuan medis malpraktik kedokteran terdapat pada pemeriksaan alat dan cara yang dipakai dalam pemeriksaan, perolehan fakta medis yang salah, diagnosa yang ditarik dari perolehan fakta, perlakuan terapi, maupun perlakuan menghindari akibat kerugian dari salah diagnosa atau salah terapi. Kelalaian/culpa adalah pengertian hukum yang pada tataran penerapannya dibidang malpraktek kedokteran belum seragam, ini menimbulkan ketidak pastian hukum. Titik penentu pertanggungjawaban hukum dalam perlakuan medis malpraktek kedokteran ada pada akibat yang ditimbulkan berupa kerugian menurut hukum.

Oleh karena itu, perlu adanya suatu kepastian hukum khusus bidang kesehatan untuk memberikan keadilan hukum bagi pasien yang dirugikan. Sebagai mana yang Undang-Undang Dasar 1945 mengamanatkan bahwa kesehatan adalah merupakan hak asasi manusia. Pada pasal $28 \mathrm{H}$ dinyatakan bahwa setiap orang berhak hidup sejahtera lahir dan batin, bertempat tinggal dan mendapatkan lingkungan hidup yang baik dan sehat serta berhak memperoleh pelayanan kesehatan. Selanjutnya pada pasal 34 ayat 3 dinyatakan bahwa negara bertanggung jawab atas penyediaan fasilitas pelayanan kesehatan dan fasilitas pelayanan umum yang layak. Hal tersebut menunjukkan bahwa pemerintah berkewajiban untuk menyehatkan yang sakit dan berupaya mempertahankan yang sehat untuk tetap seha Berdasarkan pernyataan diatas, maka tulisan ini akan mengkaji Tinjauan Yuridis penegakkan Hukum Malpraktik Dokter Pada Pelayanan Kesehatan dalam perspektif Hukum Pidana.

\section{B. METODOLOGI PENELITAN}

Berdasarkan objek masalah penelitian yang digunakan adalah penelitian yuridis normatif atau hukum normatif, yaitu hukum dikonsepsikan sebagai norma, norma, asasasas atau dogma-dogma. Menurut Soerjono Soekanto penelitian hukum normatif terdiri dari penelitian asas-asas hukum, sistematika hukum, taraf sinkronisasi hukum, sejarah hukum, dan perbandingan hukum ${ }^{7}$.

Pendekatan yang dilakukan adalah Pertama, pendekatan undang-undang (stature approach) dilakukan dengan menelaah semua undang-undang regulasi hukum yang bersangkut paut dengan isu hukum yang ditangani. Kedua, pendekatan kasus (case approach) dilakukan dengan cara melakukan telaah terhadap kasus-kasus yang berkaitan dengan isu yang dihadapi yang menjadi putusan pengadilan yang telah mempunyao kekuatan hukum tetap. Dan ketiga, Pendekatan konseptual (conseptual approach) beranjak dari pandanganpandangan dan doktrin-doktrin yang berkembang di dalam ilmu hukum. ${ }^{8}$ melakukan Menurut Soetandyo Wignjosoebroto pendekatan konseptual hukum sebagai konsep yang amat berwarna moral dan filosofis. ${ }^{9}$

\section{PEMBAHASAN}

\section{Hukum dan Fungsi Hukum Pidana}

\section{a) Pengertian Hukum Pidana}

\footnotetext{
${ }^{7}$ Bambang Sunggono, Metode Penelitian Hukum, Jakarta: PT RajaGrafindo Persada, 2010], hal. 41.

${ }^{8}$ Peter Mahmud Marzuki, Penelitian Hukum, [Jakarta: Kencana Prenada Media Group, 2010], hal. 93-95.

${ }^{9}$ Soetandyo Wignjosoebroto, Hukum Konsep dan Metode, Malang: Setara Press, 2013], hal. 22.
} 
Hukum adalah undang-undang dan sebagainnya untuk mengatur pergaulan hidup masyarakat atau patokan [ketentuan] mengenai peristiwa tertentu atau putusan [pertimbangan] yang ditetapkan hakim di pengadilan [vonis]. ${ }^{10}$ Menurut Achmad Ali, Hukum adalah seperangkat kaidah atau ukuran yang tersusun dalam suatu sistem yang menentukan apa yang boleh dan tidak boleh dilakukan oleh manusia sebagai warga dalam kehidupan bermasyarakatnya. Hukum tersebut bersumber baik dari masyarakat sendiri maupun dari sumber lain yang diakui berlakunya oleh otoritas tertinggi dalam masyarakat tersebut, serta benar-benar diberlakukan oleh warga masyarakat sebagai satu keseluruhan) dalam kehidupannya, jika kaidah itu dilanggar akan memberikan kewenangan bagi otoritas tertinggi untuk menjatuhkan sanksi yang sifatnya eksternal. ${ }^{11}$ Secara khusus hukum yang memberikan sanksi berupa sanksi fisik maupun sanksi denda/atau kurungan dalam ilmu hukum disebut dengan istilah hukum pidana. Dalam hal ini, Moeljatno menjelaskan, Hukum pidana adalah bagian dari keseluruhan hukum yang berlaku di suatu Negara, yang mengadakan dasar-dasar dan aturan-aturan untuk:

1) Menentukan perbuatan-perbuatan mana yang tidak boleh dilakukan, yang dilarang, yang disertai ancaman atau sanksi yang berupa pidana tertentu bagi siapa yang melanggar larangan tersebut.

2) Menentukan kapan dan dalam hal-hal apa kepada mereka yang melanggar laranganlarangan itu dapat dikenakan atau dijatuhi pidana sebagaimana yang telah diancamkan.

3) Menentukan dengan cara bagaiamana pengenaan pidana itu dapat dilaksanakan apabila ada orang yang disangka telah melanggar larangan tersebut. ${ }^{12}$

Hukum dalam fungsinya sebagai perlindungan kepentingan manusia, hukum mempunyai tujuan. Hukum mempunyai sasaran yang hendak dicapai. Adapun tujuan pokok hukum adalah menciptakan tatanan masyarakat yang tertib, menciptakan ketertiban, dan keseimbangan. Dengan tercapainya ketertiban dalam masyarakat diharapkan kepentingan manusia akan terlidungi. Dalam mencapai tujuan itu, hukum bertugas membagi hak dan kewajiban antar perorangan di dalam masyarakat, membagi wewenang dan mengatur cara memecahkan masalah hukum serta memelihara kepastian hukum. ${ }^{13}$

\section{b) Fungsi Hukum Pidana}

Menurut Adami Chazawi, sebagai bagian hukum public, hukum pidana memiliki fungsi sebagai berikut:

1) Fungsi melindungi kepentingan hukum dari perbuatan yang menyerang atau memperkosanya.

Kepentingan hukum adalah segala kepentingan yang diperlukan dalam berbagai segi kehidupan baik sebagai pribadi, anggota masyarakat, maupaun anggota Negara, yang wajib dijaga dan dipertahankan agar tidak dilanggar/ diperkosa oleh perbuatan-perbuatan manusia. Semua itu ditujukan untuk terlaksana dan terjaminnya ketertiban di dalam segala bidang kehidupan.

\footnotetext{
${ }^{10}$ Departemen Pendidikan Nasional, Kamus Besar Bahasa Indonesia, [Jakarta: Balai Pustaka, 2007 ], hal. 410.

${ }^{11}$ Achmad Ali, Menguak Tabir Hukum, Bogor: \{Ghalia Indonesia,2008\} hal. 30-31.

${ }^{12}$ Moeljatno, Asas-Asas Hukum Pidana, [Jakarta: Rineka Cipta, 2015], hal. 1.

${ }^{13}$ Sudikno Mertokusumo, Mengenal Hukum Suatu Pengantar, \{Yogyakarta: Universitas Atma Jaya, 2010\} hal. 99 .
} 
2) Memberi dasar legitimasi bagi Negara dalam rangka Negara menjalankan fungsi mempertahankan kepentingan hukum yang dilindungi.

Fungsi hukum pidana yang dimaksud ini tiada lain memberi dasar legitimasi bagi Negara agar Negara dapat menjalankan fungsi menegakkan dan melindungi kepentingan hukum yang dilindungi oleh hukum pidana tadi dengan sebaik-baiknya.

3) Fungsi mengatur dan membatasi kekuasaan Negara dalam rangka menjalankan fungsi mempertahankan kepentingan hukum yang dilindungi.

Dalam menjalankan fungsi hukum pidana yang disebutkan kedua, hukum pidana telah memberikan hak dan kekuasaan yang sangat besar pada Negara agar Negara dapat menjalankan fungsi mempertahankan kepentingan hukum yang dilindungi dengan sebaikbaiknya. ${ }^{14}$

\section{Pengertian Malpraktik}

Medical malpractice atau disingkat malpractice (Malpraxis) secara umum berarti praktek buruk (bad practice) yang dapat dikatakan terhadap orang yang menjalankan profesinya dengan memakai cara atau ilmunya secara tidak wajar, sehingga hal ini tidak berlaku bagi profesi medis saja tetapi juga berlaku bagi profesi lainnya seperti notaris, advokat, akuntan dan lain sebagainya. Malapraktek berasal dari kata "mala" dan "praktek", kata mala mempunyai arti petaka, kecelakaan, bencana, sedangkan kata praktek diartikan dengan cara melakukan apa yang disebut dalam teori atau menjalankan pekerjaan. Sehingga secara umum kata malapraktek dapat diartikan sebagai menjalankan pekerjaan dengan tidak baik. ${ }^{15}$

Vera Polina Br Ginting menjelaskan Istilah Malpraktik dalam kehidupan masyarakat saat ini, yaitu kelalaian profesional karena tindakan atau kealpaan oleh pihak penyedia jasa kesehatan, sehingga perawatan yang diberikan tidak sesuai dengan prosedur standar medis (SOP) sehingga mengakibatkan kondisi medis yang memburuk, atau kematian seorang pasien. Sorotan masyarakat yang cukup tajam atas jasa pelayanan kesehatan oleh tenaga kesehatan, khususnya dengan terjadinya berbagai kasus yang menyebabkan ketidakpuasan masyarakat memunculkan isu adanya dugaan malpraktek medis yang secara tidak langsung dikaji dari aspek hukum dalam pelayanan kesehatan. ${ }^{16}$

Pengertian Malpraktek Ada berbagai macam pendapat dariparasarjana mengenai pengertian malpraktek. Masing-masing pendapat itu diantaranya adalah sebagai berikut:

a. Veronica menyatakan bahwa istilah malparaktek berasal dari "malpractice" yang pada hakekatnya adalah kesalahan dalam menjalankan profesi yang timbul sebagai akibat adanya kewajibankewajiban yang harus dilakukan oleh dokter. (Anny Isfandyarie, 2005: 20).

b. Hermien Hadiati menjelaskan malpractice secara harfiah berarti bad practice, atau praktek buruk yang berkaitan dengan praktek penerapan ilmu dan teknologi medik dalam menjalankan profesi medik yang mengandung ciri-ciri

\footnotetext{
${ }^{14}$ Adami Chazawi, Pelajaran Hukum Pidana Bagian I, [Jakarta: PT RajaGrafindo Persada, 2013], hal 1720.

${ }^{15} \mathrm{https}$ //yuokysurinda.wordpress.com/ Malpraktek Dan Perlindungan Hukumnya, diakses pada tanggal 27 Januari 2020 pukul 14.30 WIB

${ }^{16}$ Vera Polina Br Ginting, Penanggulangan Malpraktek Yang Dilakukan Oleh Tenaga Kesehatan [junral: Bagian Hukum Pidana Fakultas Hukum Universitas Lampung 2017], hal. 1.
} 
khusus. Karena malpraktek berkaitan dengan "how to practice the medical science and technology", yang sangat erat hubungannya dengan sarana kesehatan atau tempat melakukan praktek dan orang yang melaksanakan praktek. Maka Hermien lebih cenderung untuk menggunakan istilah "maltreatment".

c. Pengertian malpraktek medik di dalam Black's Law Dictionary: "Malpraktek adalah setiap sikap tindak yang salah, kekurangan keterampilan dalam ukuran tingkat yang tidak wajar. Istilah ini umumn yang dipergunakan terhadap sikap tindak dari para dokter, pengacara, dan akuntan. Kegagalan untuk memberikan pelayanan professional dan melakukan pada ukurant ingkat keterampilan dan kepandaian yang wajar di dalam masyarakatnya oleh teman sejawat rata-rata dari profesi itu, sehingga mengakibatkan luka, kehilangan atau kerugian pada penerima pelayanan tersebut yang cenderung menaruh kepercayaan terhadap mereka. ${ }^{17}$

Kartono Mohammad mengatakan bahwa, "Malpraktek adalah suatu istilah hukum, suatu istilah yang sering disamakan dengan kelalaian tindakan dokter (Medical neglegence)." Selanjutnya yang juga dapat dipergunakan sebagai petunjuk adalah pengertian yang disampaikan oleh Soerjono Soekanto yang mengatakan bahwa: "istilah malpractice berarti kekeliruan profesional yang mencakup ketidak mampuan melakukan kewajiban profesional, atau lalai melakukan kewajiban profesional." 18 Menurut Kamus Besar Bahasa Indonesia [KBBI] Malpraktek adalah praktek kedokteran yang salah, tidak tepat, menyalahi undang-undang dan kode etik. $^{19}$

Malpraktik menurut Azrul Azwar memilik beberapa arti, pertama Malpraktik adalah setiap kesalahan profesional yang diperbuat oleh dokter, oleh karena pada waktu melakukan pekerjaan profesionalnya, tidak memeriksa, tidak menilai, tidak berbuat atau meninggalkan hal-hal yang diperiksa, dinilai, diperbuat atau dilakukan oleh dokter pada umunya, didalam situasi dan kondisi yang sama. Kedua, malpraktik adalah setiap kesalahan yang diperbuat oleh dokter, oleh karena dalam melakukan pekerjaan kedokteran dibawa standar yang sebenarnya secara rata-rata dan masuk akal dapat dilakukan oleh setiap dokter dalam situasi atau tempat yang sama. Ketiga, malpraktik adalah setiap kesalahan profesional di perbuat oleh seorang dokter yang didalamya termasuk kesalahan karena perbuatan-perbuatan yang tidak masuk akal serta kesalahan karena keterampilan ataupun kesetiaan yang kurang dalam menjalankan kewajiban ataupun kepercayaan profesional yang dimilikinya. ${ }^{20}$

Berdasarkan beberapa pengertian diatas, dalam hal ini, malpraktek adalah setiap kelalaian, atau penyalahgunaan profesional dokter, dan tenaga kesehatan lainnya baik secata etik dan secara hukum ketika dalam melaksanakan pelayanan kesehatan pada situasi dan tempat tertentu yang menimbulkan akibat buruk bagi pasien yang mana pasien dapat menjadi korban.

\section{Hubungan Pasien dan Dokter}

Dasar adanya kewajiban dokter adalah adanya hubungan kontraktual-profesional

\footnotetext{
${ }^{17}$ RiskaAndi Fitriono, Penegakan Hukum Malpraktik Melalui Pendekatan Mediasi Penal, [Yustisia.Vol.5 No.1 Januari - April 2016], hal. 89.

${ }^{18}$ M. Nurdin. Perlindungan Hukum Terhadap Pasien Atas Korban Malpraktek Kedokteran, [Jurnal Hukum Samudra Keadilan, Vol. 10 No. 1 Januari-Juni 2015] hal. 99.

${ }^{19}$ Departemen Pendidikan Nasional, Kamus Besar Bahasa Indonesia..., hal. 706.

${ }^{20}$ Bambang Heryanto, Malpraktik Dokter Dalam Perspektif Hukum...... hal. 184.
} 
antara tenaga medis dengan pasiennya, yang menimbulkan kewajiban umum sebagai akibat dari hubungan tersebut dan kewajiban profesional bagi tenaga medis tersebut. Kewajiban profesional diuraikan di dalam sumpah profesi, etik profesi, berbagai standar pelayanan, dan berbagai prosedur operasional. Kewajiban-kewajiban tersebut dilihat dari segi hukum merupakan rambu-rambu yang harus diikuti untuk memperoleh perlindungan, baik bagi pemberi layanan maupun bagi penerima layanan. ${ }^{21}$ Hubungan antara dokter dan pasien secara yuridis dapat dimasukkan ke dalam golongan kontrak. Suatu kontrak adalah pertemuan pikiran (meeting of minds) dari dua orang mengenai suatu hal. Pihak pertama mengikatkan diri untuk memberikan pelayanan, sedangkan pihak kedua menerima pemberian pelayana tersebut. Pasien datang kepada dokter untuk diberikan pelayanan pengobatan sedangkan dokter menerima untuk memberikannya.

Dengan demikian maka sifat hubungannya mempunyai 2 ciri: (1) Adanya suatu persetujuan (consensual agreement), atas dasar saling menyetujui dari pihak dokter dan pasien tentang pemberian pelayanan pengobatan. (2) Adanya suatu kepercayaan (fiduciary), karena hubungan kontrak tersebut berdasarkan saling percaya mempercayai satu sama lain. ${ }^{22}$

\section{Hukum dan Kode Etik Kedokteren Indonesia}

Etika profesi adalah bagian dari etika sosial, yaitu filsafat atau pemikiran kritis rasional tentang kewajiban dan tanggung jawab manusia sebagai anggota umat manusia. Dalam penerapannya di lapangan etika profesi memang selalu tidak puas dengan gambaran-gambaran empiris tentang sesuatu fenomena. Ia membutuhkan penilaian-penilaian agar dapat diterapkan. ${ }^{23}$ Dalam etik kedokteran ini mempunyai dua sisi dimana satu sisi saling terkait dan saling pengaruh mempengaruhi, yaitu etik jabatan atau medical ethics, yang menyangkut masalah yang berhubungan dengan sikap para dokter terhadap sejawatnya, sikap dokter terhadap pembantunya dan sikap dokter terhadap masyarakat. sedangkan etik asuhan atau ethics of the medical care, yaitu merupakan etik kedokteran dalam kehidupan sehari-hari mengenai sikap dan tindakan seorang dokter terhadap penderita yang menjadi tanggung jawabnya. ${ }^{24}$

Salah satu persyaratan untuk dapat mengetahui bahwa dokter telah melakukan tindakan atau proses perawatan yang benar adalah dengan mengukur pada standar profesi medis, atau standar minimal pelayanan kedokteran yang dipergunakan sebagai pedoman didalam pelaksanaan profesinya. Adapun yang dimaksud dengan standar profesi menurut Lacnen adalah berbuat secara teliti dan seksama menurut standar medis sebagai seorang dokter yang memiliki kemampuan rata-rata dibanding dengan dokter-dokter dari kaegori keahlian medis yang sama, dalam situasi dan kondisi yang sama dengan sarana upaya, (middelen) yang sebanding atau profesional dengan tujuan konkrit yang merupakan tindakan atau perbuatan medis tersebut.

${ }^{21}$ Budi Sampurno, Laporan Akhir Tim Penyusunan Kompendium Hukum Kesehatatan, [Jakarta: Pusat Penelitian Dan Pengembangan Sistem Hukum Nasional Badan Pembinaan Hukum Nasional Kementerian Hukum Dan HAM RI Tahun 2011], hal. 113.

${ }^{22}$ Priharto Adi, Formulasi Hukum Penanggulangan Malpraktik Kedokteran, [Kanun Jurnal No. 60, Th. XV Agustus, 2013], hal. 270.

${ }^{23}$ Darji Darmodiharjo, dan Shidarta, Pokok-pokok Filsafat hukum, [Jakarta: PT.Gramedia Pustaka Utama, 2004], hal. 271.

${ }^{24}$ RiskaAndi Fitriono, Penegakan Hukum Malpraktik...., hal. 89. 
Sedangkan sumber lain mengatakan bahwa standar profesi medis merupakan sesuatu yang harus dilakukan (commisio) atau tidak harus dilakukan (omissio) oleh katakata dokter dari kategori tertentu (dokter umum, spesialis, super spesialis) dalam kondisi dan situasi yang sama. Apabila diperinci lebih lanjut, maka standar profesi medis (dokter) ini terbagi ke dalam 6 (enam) unsur yaitu:

a. Berbuatnya secara teliti atau seksama (Zorg Vulding Handele)

b. Sesuai standar medis (Volgens de Medische Standard)

c. Kemampuan rata-rata (average) dibanding kategori keahlian medik yang sama (Gemeddel de Van gelijke Medische categoric).

d. Situasi dan kondisi yang sama (gelijke omstagding haiden)

e. Sarana upaya (midelen) yang sebanding atau profesional (asas profesionalitas) (met meddelendei in redelijke vet hauding stramm)

f. Dengan tujuan konkrit tindakan atau perbuatan medik tersebut atau tujuan medik (tot the concriet handelings doel).

Uraian di atas menunjukkan betapa pentingnya unsur standar medik di dalam standar profesi kedokteran karena tiap pelaksanaan pengobatan harus selalu berlandaskan pada standar medik yang berlaku. Pengertian medik menurut Leenen adalah suatu cara untuk melakukan tindakan tuduhan medik yang didasarkan kepada ilmu medik dan pengalaman. Penyusunan standar medis ini ditujukan agar pelanan kesehatan yang diberikan oleh dokter mempunyai tolak ukur yang jelas agar masyarakat mengetahui dengan pasti berapa jauh tindakan medis yang ditetapkan terhadap dirinya apakah sudah tepat atau belum. ${ }^{25}$
Akan tetapi, keberadaan hukum dan kode etik profesi menjadi masalah cukup krusial dalam pelayanan kesehatan. Pada umumnya hukum mengatur perilaku setiap warga masyarakat sedangkan kode etik mengatur bagi profesi tertentu. Namun antara hukum dan kode etik profesi terdapat persamaan dan perbedaan cukup prinsipil. Persamaan keduanya merupakan norma yang mengatur perilaku manusia dalam kehidupan bersama masyarakat. Perbedaan utama terletak pada bentuk susunan, yakni menyakut atas;

a. Lembaga/institusi yang menciptakan norma tersebut;

b. Kekuatan mengikat

c. Jenis-jenis sanksi dan akibat hukum yang dijatuhkan,

d. Lembaga/institusi yang menjatuhkan sanksi, dan

e. Kriteria yang digunakan sebagai tolak ukur ada atau tidaknya perbuatan kesalahan/kelalaian.

Perbedaan antara etika profesi dengan hukum yang sesungguhnya, oleh Hermein Hadiati koeswadji, menjelaskan, etika profesi memiliki ciri-ciri khas, yaitu;

a. Mengatur perilaku pelaksana/pengemban profesi,

b. Dibuat berdasarkan adanya consensus/ kesepakatan di antara para pelaksana pengemban,

c. Kekuatan mengikatnya untuk satu waktu tertentu dan mengenai satu hal tertentu,

d. Sifat sanksinya moral dan psikologis,

e. Macam sanksinya dapat berupa diskreditasi profesi,

f. kontrol dan penilaiannya atas pelaksananya dilakukan oleh ikatan/ organisasi profesi terkait.

Semenata itu, hukum memiliki ciri-ciri, yaitu:

${ }^{25}$ M. Nurdin. Perlindungan Hukum Terhadap Pasien...., hal. 102. 
a. Mengatur perilaku manusia pada umumnya,

b. Dibuat oleh lembaga resmi Negara yang berwenang bagi setiap orang,

c. Mengikat sebagai sesuatu yang wajib secara umum sampai dicabut/diganti dengan yang baru,

d. Sifat sanksinya adalah berupa derita jasmani/materiil [lichamelik leed],

e. Macam sanksinya dapat berupa pidana [straf], ganti rugi [schandevergoeding] atau tindakan [maatregel], dan

f. kontrol dan penilaian atas pelaksanaannya dilakukan oleh warga masyarakat dan lembaga resmi dari aparat penegak hukum struktural. ${ }^{26}$

Teguh Sulistia, menjelaskan, dari segi hukum kesalahan/kelalaian selalu terikat dengan sifat melawan hukum suatu perbuatan dilakukan oleh orang yang mampu untuk bertanggung jawab. Oleh karena itu, setiap perbuatan orang yang mampu bertanggung jawab dalam ilmu hukum dirumuskan sebagai perbuatan yang dapat dipidana atau tindak pidana [strafbaarfeit]. Tindak pidana merupakan istilah dalam ilmu hukum pidana yang menunjuk kepada kelakuan orang [menselijke gedraging] yang dirumuskan dalam undang-undang yang bersifat melawan hukum oleh karena itu patut dipidana [strafwaarding] bagi para pelaku dan dilakukan dengan adanya kesalahan. ${ }^{27}$

\section{Kasus-kasus Malpraktik yang terjadi di Indonesia}

Ada ungkapan 'Dokter Juga Manusia'. Artinya, sebagai manusia, wajar kalau dokter melakukan kesalahan. Ungkapan itu memang benar. Tapi bila memperhatikan kasus-kasus malpraktik di dunia kedokteran selama ini. Di Indonesia misalnya, ada kasus bayi yang salah potong jari, salah tranfusi darah, salah suntik, hingga salah diagnosis yang berujung pada kematian. Berikut ini beberapa kasus malpraktek yang dilakukan oleh dokter dan tenaga kesahatan yang terjadi di Indonesia.

\section{a. Infeksi Pasca Operasi Cesar}

Kasus malpraktik ini terjadi di Bintan Utara, seorang perempuan berusia 30 tahun mengalami infeksi pasca operasi cesar. Bahkan perutnya berlubang dan mengeluarkan bau busuk. Diketahui perempuan tersebut menjalani rawat inap selama tiga hari pasca operasi cesar. Selama tiga hari itu pula, rupanya pihak rumah sakit tak memeriksa luka bekas operasi, bahkan tak mengganti perbannya. Setelah itulah ia mengeluh sakit di bagian perut. Saat dilihat, ternyata dinding perut istrinya sudah basah dan menimbulkan bau bahkan berlubang.

\section{b. Kesalahan Menangani Persalinan}

Berikutnya ada malpraktik yang terjadi di Palembang, sepasang suami istri harus menerima kenyataan pahit jika bayi mereka ternyata tewas usai dilahirkan dengan kondisi leher patah dan kulit terkelupas. Kondisi ini diduga terjadi karena kesalahan bidan dalam menangani proses persalinan sang istri. Menurut keterangan, rupanya ini bukan kali pertama ada kasus bayi meninggal di tangan bidan tersebut. Pihak keluarga pun akhirnya melaporkan hal ini ke pihak berwajib.

\section{c. Kebutaan Pasca Operasi Usus Buntu}

Kali ini nasib tragis dialami seorang anak berusia 14 tahun asal Nusa Tenggara Timur. Setelah jalani operasi usus buntu, mata kanannya malah mengalami kebutaan. Padahal sebelumnya kedua matanya baik-baik saja.

\footnotetext{
${ }^{26}$ Teguh Sulistia, Hukum Pidana Horizon..., hal. 233-234.

${ }^{27}$ Teguh Sulistia, Hukum Pidana Horizon..., hal. 234.
} 
Awalnya mata kanannya hanya bengkak, ayah pasien pun mengeluhkan kondisi mata kanan anaknya yang mulai memburuk, hingga lama kelamaan penglihatan dari mata kanannya tersebut benar-benar hilang.

\section{d. Salah Obat}

Lagi-lagi malpraktik menyebabkan kebutaan, mulanya warga yang berprofesi sebagai petani di Kabupaten Bone ini memeriksakan diri dengan keluhan sakit di bagian kepalanya. Dokter pun memberikan obat berupa salep kepada pasiennya dengan cara mengoleskan salep kulit di bagian pinggir mata atas dan bawah. Tidak lama setelah dioleskan kedua matanya terasa panas dan tidak dapat melihat sama sekali. $^{28}$

\section{e. Kasus Suntikan Maut}

Terakhir kasus malpraktik yang terjadi di Rumah Sakit Cut Nyak Dhien (RSCUND) Meulaboh-Kabupaten Aceh Barat yang dilakukan oleh tenaga medis yang mengakibatkan kematian pasien setelah disuntik atas nama Alfa Reza. Pihak protes lantaran pasien meninggal dunia setelah disuntik petugas medis. Sebelumnya, korban sempat menjalani perawatan usai dioperasi di Ruang Anak. Aflareza meninggal dunia lima menit mendapat suntikan lebih dari dua kali dari tim medis RSCUND. Pihak rumah sakit membenarkan insiden tersebut dan mengakui ada dua anak yang meninggal setelah disuntik oleh tim medis.

\section{Proses Pelaksanaan Penegakkan Hukum Pidana Malpraktik Tenaga Kesehatan}

Setiap tindak pidana selalu terdapat unsur sifat melawan hukum. Pada sebagian kecil tindak pidana sifat melawan hukum dicantumkan secara tegas dalam rumusan, tetapi pada sebagian larangan berbuat, maka setiap tindak pidana mengandung unsur sifat melawan hukum. Bagi tindak pidana yang tidak mencantumkan unsur sifat melawan hukum dalam rumusannya, unsur tersebut terdapat secara terselubung pada unsur-unsur yang lain. Bisa melekat pada unsur perbuatan, objek perbuatan, akibat perbuatan atau unsur keadaan yang menyertainya.

Kasus-kasus malpraktek seperti gunung es hanya sedikit yang muncul dipermukaan. Ada banyak tindakan dan pelayanan medik yang dilakukan dokter atau tenaga medis lainnya yang berpotensi merupakan malpraktek yang dilaporkan masyarakat tapi tidak diselesaikan secara hukum. Bagi masyarakat hal ini sepertinya menunjukkan bahwa para penegak hukum tidak berpihak pada pasien terutama masyarakat kecil yang kedudukannya tentu tidak setara dengan tenaga medis.

Secara umum letak sifat melawan hukum malpraktek dibidang kesehatan terletak pada dilangarnya kepercayaan atau amanah pasien dalam kontrak terapeutik. Kepercayaan atau amanah tersebut adalah kewajiban tenaga kesehatan untuk berbuat sesuatu dengan sebaik-baiknya, secermat cermatnya, penuh kehati-hatian, tidak berbuat ceroboh, berbuat yang seharusnya diperbuat dan tidak berbuat apa yang seharusnya tidak diperbuat. Secara khusus latak sifat melawan hukum perbuatan malpraktek tidak selalu sama, bergantung pada kasus, terutama syarat yang menjadi penyebab timbulnya malpraktek. Faktor sebab dalam kasus malpraktek selalu ada, yaitu timbulnya akibat yang merugikan kesehatan atau nyawa pasien. $^{29}$

Dalam ilmu hukum setiap kasus/perkara terjadi dituntut adanya pertanggung jawaban

\footnotetext{
${ }^{28}$ https://parenting.orami.co.id/6 Kasus Malpraktik Paling Mengerikan di Indonesia/diakses pada tanggal 29 Januari 2020 pukul 10.20 WIB

${ }^{29}$ Vera Polina Br Ginting, Penanggulangan Malpraktek..., hal. 4.
} 
hukum. Tanggungjawab hukum dapat dibedakan dalam tanggungjawab hukum administrasi, tanggungjawab hukum perdata dan tanggungjawab hukum pidana. Terhadap pelanggaran-pelanggaran hukum tersebut yang dilakukan oleh profesi dokter ini dapat dilakukan tindakan atau dengan kata lain dilakukan penegakan hukum. Yang menjadi konsentrasi pertanggungjawaban dalam hal ini adalah tanggungjawab pidana, dimana pertanggungjawaban hukum pidana adalah kebebasan seseorang untuk dan tidak melakukan sesuatu, dimana penegakan hukumnya dilakukan oleh aparat penegak hukum yang berwenang.

Penegakkan hukum merupakan hal yang sangat essensial pada suatu negara hukum yang mengutamakan berlakunya hukum negara berdasarkan undang-undang (state law) guna dapat terwujud tujuan hukum, yaitu keadilan dalam kehidupan bermasyarakat dan bernegara. Ini berarti seluruh kegiatan berkenaan dengan upaya melaksanakan, memelihara dan mempertahankan positif sehingga hukum tidak kehilangan makna dan fungsinya sebagai pedoman dalam mematuhi normanorma yang berlaku dalam kehidupan bermasyarakat dan bernegara, yaitu perlindungan kepentingan manusia, baik secara perorangan maupun seluruh warga masyarakat. ${ }^{30}$

Penegakkan hukum pidana malpraktek kedokteran diartikan sebagai sebagai penggunaan atau penerapan instrumeninstrumen dan sanksi-sanksi dalam lapangan hukum pidana, dengan tujuan memaksa subjek hukum yang menjadi sasaran mematuhi peraturan perundang-undangan. Atau penggunakan sanksi kepada tenaga kesehatan yang telah melakukan perbuatan melawan hukum yang mengkibatkan kerugian bagi pasien. Dalam Penegakkan hukum pidana malpraktek ada tiga unsur yang harus diperhatikan yaitu unsur kepastian hukum, kemanfaatan dan keadilan. Dengan adanya kepastian hukum pelayanan kesehatan akan lebih tertib. masyarakat juga mengharapkan manfaat yang diperoleh dari tegaknya hukum itu. Dalam pelaksanaan penegakkan hukum masyarakat mengharapkan juga agar hukum bisa memberikan keadilan bagi kepentingan mereka.

Kemanfaatan dalam penegakkan hukum salah satunya dimaksud untuk pembangunan masyarakat, termasuk didalamnya pembangunan kesehatan masyarakat. Pembangunan kesehatan masyarakat diarahkan untuk meningkatkan derajat kesehatan, sangat besar manfaatnya bagi pembangunan dan pembinaan sumberdaya manusia Indonesia. Adapun mengenai pelaksanaan penegakkan hukum malpraktik melalui sarana peraturan perundangundangan, yaitu peraturan yang diatur didalam KUHP dan Undang. Undang Nomor 36 Tahun 2014 Tentang Tenaga Kesehatan:

\section{a. Penegakkan Hukum Pidana Malpraktek} Dalam KUHP

Profesi sebagai dokter tidaklah mudah karena banyak dokter dalam dunianya sering melakukan tindakan malpraktek sehingga berakibat kepada kesalahan medis yang menyebabkan pasien cacat ataupun meninggal dunia, maka didalam praktek agar tidak menimbulkan kesemena-menaan dari seorang dokter terhadap pasiennya perlu diadakannya pertanggungjawaban hukum secara pidana, yang dimana jika dikaji dari KUHP terhadap dokter yang melakukan tindakan malpraktek dapat dipertanggungjawabkan perbuatannya dengan Pasal 360 KUHP pada ayat (1) dan (2)

${ }^{30}$ Budi Handoyo, Legalitas Lingkungan Hidup dalam Perspektif Keadilan dan Hukum Administrasi Negara, [Al-Ijtima'I Vol. 2 No. 2 Maret 2017], hal. 35. 
sehingga terhadap dokter yang melakukan tindakan medis yang berakibat menimbulkan luka berat atau kematian karena kelalaian dokter terhadap pasiennya dapat mempertanggungjawabkan secara pidana, dengan tujuan untuk melindungi hak terhadap korban yang mendapatkan tindakan malpraktek.

Malpraktik kedokteran pidana hanya terjadi pada tindak pidana materiil (KUHP), yaitu suatu tindak pidana yang melarang menimbulkan akibat tertentu yang diancam dengan sanksi berupa pidana. Timbulnya akibat, menjadi syarat selesainya tindak pidana. Adapun akibat yang menjadi unsur malpraktik kedokteran pidana adalah kematian, luka berat, rasa sakit, atau luka yang mendatangkan penyakit, atau luka yang menghambat tugas dan mata pencaharian. Di dalam KUHP, perbuatan yang menyebabkan orang lain luka berat atau mati yang dilakukan secara tidak sengaja dirumuskan didalam Pasal 359 dan 360. Adapun unsur-unsur dari pasal 359 dan 360 adalah sebagai berikut:

1) Adanya unsur kelalaian (culpa)

2) Adanya wujud perbuatan tertentu

3) Adanya akibat luka berat atau matinya orang lain

4) Adanya hubungan kausal antara wujud perbuatan dengan akibat kematian orang lain itu,

Jika 4 unsur diatas dibandingkan dengan unsur pembunuhan dalam pasal 338, maka terlihat bahwa unsur 2,3 dan 4 dari pasal 359 tidak ada bedanya dengan unsur pembunuhan dalam pasal 338. Perbedaannya hanya terletak pada unsur kesalahannya yaitu pasal 359 kesalahan dalam bentuk kurang hai-hati (kulpa), sedangkan kesalahan dalam pasal 338 (pembunuhan) dalam bentuk kesengajaan. Dalam hal ini, R. Soesilo menjelaskan "Mati orang disini [ pada pasal 359] tidak dimaksud sama sekali oleh terdakwa, akan tetapi kematian terserbut hamya merupakan akibat dari kurang hati-hati atau lalainya terdakwa [delik culpa]."31 Seperti kasus malpraktik yang terjadi di Rumah Sakit Cut Nyak Dhien (RSCUND) Meulaboh-Kabupaten Aceh Barat yang dilakukan oleh tenaga medis yang mengakibatkan kematian pasien setelah disuntik. Dalam hal adanya malpraktik kedokteran pidana atau malpraktik tenaga medis (crime malpractive), pertanggungjawaban pidana itu harus dapat dibuktikan tentang adanya kesalahan profesional, misalnya kesalahan diagnosis atau kesalahan cara pengobatan atau perawatan.

Dalam hal korban malpraktik kedokteran pidana mengalami luka berat, atau luka yang mendatangkan penyakit, atau luka yang menghambat tugas dan mata pencaharian, ketentuan pidananya diatur pada Pasal 360 ayat (1) yang berbunyi: "Barang siapa karena kesalahannya (kealpaannya) menyebabkan orang lain mendapat luka-luka berat, diancam dengan pidana penjara paling lama lima tahun atau pidana kurungan paling lama satu tahun". Ayat (2): "Barangsiapa karena kesalahannya (kealpaannya) menyebabkan orang lain luka-luka sedemikian rupa sehingga timbul penyakit atau halangan menjalankan pekerjaan, jabatan atau pecaharian selama waktu tertentu, diancam dengan pidana penjara paling lama sembilan bulan atau pidana kurungan paling lamaenam bulan atau pidana denda paling tinggi empat ribu lima ratus rupiah."

Akan tetapi peraturan yang mengatur tindak pidana malpraktek didalam KUHP belum secara jelas mengatur kualifikasi dan jenis-jenis tindakan malpraktek yang ada dalam bidang kedokteran, peraturan didalam KUHP hanya mengatur lebih kepada akibat

\footnotetext{
${ }^{31}$ R. Soesilo, Kitab Undang-Undang Hukum Pidana [KUHP] Serta komentar-komentarnya Lengkap Pasal demi Pasal, [Bogor: Politeia, 1994], hal. 248.
} 
dari perbuatan malpraktek tersebut, sehingga perlu adanya peraturan baru didalam KUHP yang secara khusus mengatur tentang kualifikasi tindakan malpraktek yang dilakukan dokter, sehingga dokter tersebut dapat mempertanggungjawabkan tindakannya secara pidana dan penegak hukum dapat memiliki landasan yuridis yang jelas dalam menegakan peraturan didalam KUHP terhadap dokter yang melakukan tindakan malpraktek.

b. Penegakkan Hukum Pidana Malpraktek Menurut UU No. 36 Tahun 2009 Tentang Kesehatan Dan UU No. 36 Tahun 2014 Tentang Tenaga Kesehatan

Kesehatan sebagai hak asasi manusia harus diwujudkan dalam bentuk pemberian berbagai pelayanan kesehatan kepada seluruh masyarakal melalui penyelenggaraan pembangunan kesehatan yang menyeluruh oleh Pemerintah, Pemerintah Daerah, dan masyarakat secara terarah, terpadu dan berkesinambungan, adil dan merata, serta aman, berkualitas, dan terjangkau oleh masyarakaL Namun dalam hal menjaga kesehatan tentu seringkali ditemukan beberapa tindakan-tindakan yang mengancam kesehatan yang dapat berupa kesengajaan, kelalaian, ataupun kecelakaan. Hal-hal seperti ini dapat dikategorikan sebagai malpraktek. Selain penegakkan hukum tindak pidana malpraktek yang telah diatur dalam pasal 529 dan Pasal 360 KUHP, untuk memberikan jaminan kepastian hukum yang lebih kuat, penanganan malpraktek kedokteran dan tenaga kesehatan juga diatur dalam UU No. 36 Tahun 2009 Tentang Kesehatan Dan UU No. 36 Tahun 2014 Tentang Tenaga Kesehatan.

Sartika Damopolii, menjelaskan Dalam Undang-Undang Nomor 36 Tahun 2009 tentang Kesehatan telah diatur tentang kebutuhan akan perlindungan hukum bagi para ahli. Para ahli dalam bidang kesehatan, misalnya tenaga medis, dalam melaksanakan profesinya melakukan suatu pekerjaan yang kadang-kadang penuh risiko. Kalau yang bersangkutan telah melakukan tugasnya dengan benar menurut tolak ukur profesional (standar profesi), maka yang bersangkutan harus mendapat perlindungan hukum. ${ }^{32}$

Akan tetapi, dalam UU No. 36 Tahun 2009 Tentang Kesehatan tidak dicantumkan pengertian tentang Malpraktek, namun didalam Ketentuan Pidana pada Bab XX diatur didalam Pasal 190 yaitu:

1. Pimpinan fasilitas pelayanan kesehatan dan/atau tenaga kesehatan yang melakukan praktik atau pekerjaan pada fasilitas pelayanan kesehatan yang dengan sengaja tidak memberikan pertolongan pertama terhadap pasien dalam keadaan gawat darurat sebagaimana dimaksud dalam Pasal 32 ayat (2) atau Pasal 85 ayat (2) dipidana dengan pidana penjara paling lama 2 (dua) tahun dan denda paling banyak Rp.200.000.000 (dua ratus juta rupiah); 2 . Dalam hal perbuatan sebagaimana dimaksud pada ayat (1) mengakibatkan terjadinya kecacatan atau kematian, pimpinan fasilitas pelayanan kesehatan dan/atau tenaga kesehatan tersebut dipidana dengan pidana penjara paling lama 10 (sepuluh) tahun dan denda paling banyak satu miliar rupiah. ${ }^{33}$

Selain ketentuan pidana yang diatur dalam UU No. 36 Tahun 2009 terkait Malpraktek, juga diatur dalam UU No. 36 Tahun 2014 Tentang Tenaga Kesehatan yang

${ }^{32}$ Sartika Damopolii, Tanggung Jawab Pidana Para Medis Terhadap Tindakan Malpraktek Menurut Undang-Undang Nomor 36 Tahun 2009 Tentang Kesehatan, [Jurnal: Lex Crimen Vol. VI/No. 6/Ags/2017] hal. 60.

\footnotetext{
${ }^{33}$ Pasal 190 Undang-Undang Nomor. 36 Tahun 2009 Tentang Kesehatan[LN Tahun 2009 No.145]
} 
mana diatur dalam Bab XIV pada Pasal 84 yaitu:

1. Setiap Tenaga Kesehatan yang melakukan kelalaian berat yang mengakibatkan Penerima Pelayanan Kesehatan luka berat dipidana dengan pidana penjara paling lama 3 (tiga) tahun;

2. Jika kelalaian berat sebagaimana dimaksud pada ayat (1) mengakibatkan kematian, setiap Tenaga Kesehatan dipidana dengan pidana penjara paling lama 5 (lima) tahun. ${ }^{34}$

Pembentukan perundang-undangan di bidang pelayanan kesehatan diperlukan, hal ini dilakukan agar pelaku tindak pidana malpraktek dapat dijerat dengan ketentuan yang tegas serta tuntutan korban dapat direalisasikan dengan pembentukan UndangUndang yang berkaitan dengan kesehatan serta pelanggaran kesehatan bagi setiap orang.

Dengan diundagkannya UU No. 36 Tahun 2014 Tentang Tenaga Kesehatan pada tanggal 17 Oktober 2014 memberikan jaminan kepastian hukum penegakkan pidana tindak malpraktek yang dilakukan oleh dokter dan tenaga medis. Mengenai bentuk hukum pidana malpraktek UU No. 36 Tahun 2014 Tentang Tenaga Kesehatan adalah Lex Posterior Derogat Legi Priori, mengalahkan Undang-Undang yang lebih terdahulu. Berdasarkan pada ketentuan antara UU No. 36 Tahun 2009 Tentang Kesehatan maka Ketentuan Pidananya dapat diterapkan berdasarkan ketentuan pidana yang ditentukan dalam UU No. 36 Tahun 2014 Tentang Tenaga Kesehatan yaitu dengan ketentuan pidana paling lama lima tahun. Demikian pula pernyataan berdasarkan Asas lainnya yaitu Lex Specialis Derogat Legi Generali (bahwa peraturan yang Khusus mengalahkan peraturan yang umum). UU No. 36 Tahun 2014 Tentang Tenaga Kesehatan merupakan kekhususan dari pasal 259 dan Pasal 360 KUHP.

\section{KESIMPULAN}

Berdasarkan uraian hasil penelitian diatas, berikut ini dikemukakan beberapa kesimpulan dan disertai pula beberapa saran.

1. Malpraktik kedokteran pidana hanya terjadi pada tindak pidana materiil (KUHP), yaitu suatu tindak pidana yang melarang menimbulkan akibat tertentu yang diancam dengan sanksi berupa pidana. Proses penegakkan hukum pidana dalam menangani kasus malpraktek kedokteran diatur didalam Pasal 360 ayat (1) dan (2) KUHP yang memuat unsur-unsur kelalaian (kulpa) dokter atau tenaga medis, Adanya wujud perbuatan tertentu yaitu bentuk dari malpraktek yang dilakukan dokter atau tenaga medis, adanya akibat luka berat atau matinya pasien dan adanya hubungan kausal antara wujud perbuatan dengan akibat kematian orang lain itu.

2. Selain penegakkan hukum tindak pidana malpraktek yang telah diatur dalam KUHP, untuk memberikan jaminan kepastian hukum yang lebih kuat, penanganan malpraktek kedokteran dan tenaga kesehatan juga diatur dalam UU No. 36 Tahun 2009 Tentang Kesehatan Dan UU No. 36 Tahun 2014 Tentang Tenaga Kesehatan.

\section{Saran}

a. Disarankan kepada pihak aparat penegak hukum, dapat berperan aktif dan melihat dengan jeli indikasi-indikasi kasus malapraktek ini. Selanjutnya, sebagai rangkaian dalam keaktifannya dalam mencari penegakan hukum, Kejaksaan sebagai Penuntut Umum dan sebagai pengawasan penyidik sesuai dengan isi KUHP, dapat meningkatkan peranannya dengan jalan membina kerja sama yang

${ }^{34}$ Pasal 84 Undang.Undang Nomor 36 Tahun 2014 Tentang Tenaga Kesehatan [LN Tahun 2014 No.298] 
erat dengan pihak penyidik (polisi) untuk dapat membongkar kasus-kasus malapraktek yang selama ini masih banyak yang tertutup.

b. Selain ditegakkannya substansi hukum dan alat penegak hukum, juga perlu dilibatkan partisipasi masyarakat untuk mengantisipasi kerugian baik dipihak dirinya selaku pasien dan atau keluarganya maupun dokter.

c. Disarankan kepada pemerintah baik pusat maupun daerah untuk dilakukannya penyuluhan kesehatan kepada pihak pelayan kesehatan dengan menghimbau masyarakat untuk dapat memberikan informasi secara jelas mengenai perjalanan penyakitnya kepada dokter sehingga dokter tidak salah dalam menentukan diagnosa yang akibatnya akan mempengaruhi keberhasilan terapi pada pasien.

\section{DAFTAR PUSTAKA}

Achmad Ali, Menguak Tabir Hukum, Ghalia Bogor, cetakan kedua 2008

Adami Chazawi, Pelajaran Hukum Pidana Bagian I, PT RajaGrafindo Persada, Jakarta: 2013

Bambang Heryanto, Malpraktik Dokter Dalam Perspektif Hukum Jurnal Dinamika Hukum. Vol. 10 No. 2 Mei 2010 .

Bambang Sunggono, Metode Penelitian Hukum, PT RajaGrafindo Persada Jakarta, 2010

Budi Handoyo, Legalitas Lingkungan Hidup dalam Perspektif Keadilan dan Hukum Administrasi Negara, Al-Ijtima'I Vol. 2 No. 2 Maret 2017

Budi Sampurno, Laporan Akhir Tim Penyusunan Kompendium Hukum
Kesehatatan, Pusat Penelitian Dan Pengembangan Sistem Hukum Nasional Badan Pembinaan Hukum Nasional Kementerian Hukum Dan HAM RI Tahun Jakarta: 2011.

C. Maya Indah S. Perlindungan Korban Suatu Perspektif Viktimologi dan Kriminologi, Kencana Prenadamedia Group, Jakarta: 2014.

Darji Darmodiharjo, dan Shidarta, Pokokpokok Filsafat hukum, PT. Gramedia Pustaka Utama, Jakarta 2004.

Departemen Pendidikan Nasional, Kamus Besar Bahasa Indonesia, Balai Pustaka, Jakarta, 2007.

Hardisman, Opini Masyarakat Tentang Malpraktek Kedokteran, Majalah Kedokteran Andalas No.1. Vol.36. Januari-Juli 2012.

M. Ali. Zaidan, Kebijakan Kriminal Sinar Grafika Jakarta, 2016.

M. Nurdin. Perlindungan Hukum Terhadap Pasien Atas Korban Malpraktek Kedokteran, Jurnal Hukum Samudra Keadilan, Vol. 10 No. 1 Januari-Juni 2015

Moeljatno, Asas-Asas Hukum Pidana, Rineka Cipta, Jakarta: 2015

Peter Mahmud Marzuki, Penelitian Hukum, Kencana Prenada Media Group, Jakarta, 2010

Priharto Adi, Formulasi Hukum Penanggulangan Malpraktik Kedokteran, Kanun Jurnal No. 60, Th. XV Agustus, 2013

R. Soesilo, Kitab Undang-Undang Hukum Pidana [KUHP] Serta komentarkomentarnya Lengkap Pasal demi Pasal, Politeia, Bogor: 1994

Riska Andi Fitriono, Penegakan Hukum Malpraktik Melalui Pendekatan 
Budi Handoyo, Tinjauan Yuridis Penegakan Hukum ...

Mediasi Penal, Yustisia.Vol.5 No.1 Topo Santoso dan Eva Achjani Zulfa, Januari - April 2016

Sartika Damopolii, Tanggung Jawab Pidana

Para Medis Terhadap Tindakan

Malpraktek Menurut Undang-Undang Nomor 36 Tahun 2009 Tentang Kesehatan, Jurnal: Lex Crimen Vol. VI/No. 6/Ags/2017

Sudikno Mertokusumo, Mengenal Hukum Suatu Pengantar, Universitas Atma Jaya, Yogyakarta, 2010

Soetandyo Wignjosoebroto, Pergeseran Paradigma dalam Kajian-Kajian Sosial dan Hukum, Setara Press, Malang, 2013.

Teguh Sulistia dan Aria Zurnetti, Hukum Pidana Horizon Baru Pasca Reformasi, Raja Grafindo Persada, Jakarta, 2012 Kriminologi, Rajawali Persi, Jakarta 2006.

Vera Polina $\mathrm{Br}$ Ginting, Penanggulangan Malpraktek Yang Dilakukan Oleh Tenaga Kesehatan, jurnal: Bagian Hukum Pidana Fakultas Hukum Universitas Lampung 2017.

Undang-Undang Nomor 36 Tahun 2009 Tentang Kesehatan

Undang-Undang Nomor 36 Tahun 2014 Tentang Tenaga Kesehatan

https://yuokysurinda.wordpress.com/ Malpraktek dan Perlindungan Hukumnya, diakses pada tanggal 27 Januari 2020 pukul 14.30 WIB.

https://parenting.orami.co.id/ $6 \quad$ Kasus Malpraktik Paling Mengerikan di Indonesia, diakses pada tanggal 29 Januari 2020 pukul 10.20 WIB 